Federal Reserve Bank of Minneapolis Research Department

\title{
Do Newspapers Matter? Short-Run and Long-Run Evidence from the Closure of The Cincinnati Post*
}

\author{
Sam Schulhofer-Wohl and Miguel Garrido \\ Working Paper 686
}

April 2011

\begin{abstract}
The Cincinnati Post published its last edition on New Year's Eve 2007, leaving the Cincinnati Enquirer as the only daily newspaper in the market. The next year, fewer candidates ran for municipal office in the Kentucky suburbs most reliant on the Post, incumbents became more likely to win reelection, and voter turnout and campaign spending fell. These changes happened even though the Enquirer at least temporarily increased its coverage of the Post's former strongholds. Voter turnout remained depressed through 2010, nearly three years after the Post closed, but the other effects diminished with time. We exploit a difference-in-differences strategy and the fact that the Post's closing date was fixed 30 years in advance to rule out some non-causal explanations for our results. Although our findings are statistically imprecise, they demonstrate that newspapers even underdogs such as the Post, which had a circulation of just 27,000 when it closed - can have a substantial and measurable impact on public life.
\end{abstract}

Keywords: Newspapers; Elections; Joint operating agreements

JEL: L82, D72, K21, N82

\footnotetext{
${ }^{*}$ Schulhofer-Wohl: Federal Reserve Bank of Minneapolis and National Bureau of Economic Research. Garrido: Consultant, Edgeworth Economics. A previous version of this paper circulated under the title "Do Newspapers Matter? Evidence from the Closure of The Cincinnati Post." We are grateful to employees of The Cincinnati Post and the E.W. Scripps Co., several of whom requested anonymity, for helpful conversations. They are not responsible in any way for the content of this paper. We also thank Alícia Adserà, Anne Case, Taryn Dinkelman, Ying Fan, Douglas Gollin, Bo Honoré, James Schmitz, Jesse Shapiro, and numerous seminar participants for valuable suggestions, and Joan Gieseke for editorial assistance. Miryam Hegazy, Tony Hu, and Xun Liu provided excellent research assistance. The views expressed herein are those of the authors and not necessarily those of the Federal Reserve Bank of Minneapolis, the Federal Reserve System, or Edgeworth Economics.
} 
"Give light and the people will find their own way."

- motto of the E.W. Scripps Co., owner of The Cincinnati Post

\section{Introduction}

A century ago, 689 cities in the United States had competing daily newspapers; by 2008, only 15 did, and today that number has fallen to $11 .^{1}$ Many monopoly newspapers are also struggling financially. The decline in competition and in the newspaper industry as a whole has prompted concern that the nation is losing a crucial source of information about public affairs. In the words of one observer, "More of American life will occur in shadows. We won't know what we won't know." ${ }^{2}$

This paper offers a case study of the consequences of closing a newspaper. The Cincinnati Post published its last edition Dec. 31, 2007, leaving the Cincinnati Enquirer as the only daily newspaper covering Cincinnati and its suburbs in southern Ohio and northern Kentucky. The closing was particularly important in the northern Kentucky suburbs, where the Post historically dominated circulation and, as we document, provided more than 80 percent of the combined local news coverage in the two papers. We use a difference-in-differences strategy to show that the Post's closing made municipal politics in the Kentucky suburbs less competitive along several dimensions: Fewer people voted in elections for city council, city commission, and school board; fewer candidates sought those seats; the remaining candidates spent less money on their campaigns; and, for councils and commissions, incumbents' chances of retaining office improved. These changes happened even though the Enquirer at least temporarily increased its coverage of the Post's former strongholds. The differences appeared immediately after the Post closed; in the case of voter turnout, the impact persisted through the 2010 general election, nearly three years later, while the other effects diminished with time.

\footnotetext{
${ }^{1}$ The 1909-1910 figure is from Busterna and Picard (1993). Today's precise count depends on the definition of competing newspapers. Cities with major competing, separately owned dailies include Boston; Charleston, W.Va.; Chicago; Detroit; Fort Wayne, Ind.; Los Angeles; New York; Salt Lake City; Trenton, N.J.; York, Pa.; and Washington. Denver, Seattle, and Tucson, Ariz., all dropped from the list in 2009, with the closures of the Rocky Mountain News, Post-Intelligencer, and Citizen, respectively. Honolulu fell from the list in 2010 with the merger of the Advertiser and Star-Bulletin.

${ }^{2}$ Tom Rosenstiel, director of the Pew Research Center's Project for Excellence in Journalism, quoted in Starr (2009).
} 
We do not report analyses of election results in the Ohio suburbs because the Post largely withdrew from covering these suburbs as early as 2001 (Philipps, 2007; Rutledge, 2007), implying that the closing itself would not be expected to have much impact in Ohio. ${ }^{3}$ In results not reported here, we apply to the Ohio suburbs the same methods used in this paper to analyze the Kentucky suburbs and estimate a negative effect of the Post's closing on political activity in Ohio, but the effect is statistically insignificant and much less precisely estimated than the already imprecise estimates in Kentucky. ${ }^{4}$

Our results shed light on two important public policy concerns. First, our findings suggest that even a small newspaper - the Post sold about 27,000 copies daily in 2007, compared with 200,000 for the Enquirer — can make local politics more vibrant. Although competing publications or other media such as TV, radio, and the Internet may take up some slack when a newspaper closes, none of these appears so far to have fully filled the Post's role in municipal politics in northern Kentucky. Our findings confirm the fears of community leaders such as Boone County Judge-Executive Gary Moore, who said on learning of the Post's impending closure: "I'm very concerned about Northern Kentucky news getting to our constituents. The Post has done a wonderful job through the years of being the daily informant of what's going on in the community to our residents" (Duke, 2007). To the extent that our findings apply beyond Cincinnati, they also suggest that local politics will become less competitive after closures of the much larger second newspapers in cities such as Denver and Seattle (where the Rocky Mountain News and the Post-Intelligencer, respectively, ceased printing in 2009) or of monopoly papers in places such as Ann Arbor, Mich. (where The Ann Arbor News closed two years ago).

Second, the Post, an afternoon newspaper whose weekday circulation fell nearly 90 percent in its last 30 years, ${ }^{5}$ survived as long as it did thanks to an implicit government sub-

\footnotetext{
${ }^{3}$ By 2007, just 30 percent of the Post's weekday circulation was in Ohio, even though three-quarters of the Cincinnati Metropolitan Statistical Area's population is in Ohio; on weekdays the Post reached just 2.4 percent of households in Hamilton County (which includes Cincinnati), compared with 13.9 percent of households in Kenton County and 16 percent of households in Campbell County in Kentucky (Audit Bureau of Circulations, 2007).

${ }^{4}$ We do not analyze elections in Ohio around the time that the Post reduced its coverage there because, unlike the timing of the paper's closing, the timing of the coverage reduction in Ohio was not predetermined and may have been endogenous. We also cannot use the Ohio suburbs as a control group for comparison with the Kentucky suburbs because Ohio and Kentucky hold municipal elections in different years.

${ }^{5}$ According to the Editor 8 Publisher International Yearbook, the Post's Ohio and Kentucky editions had
} 


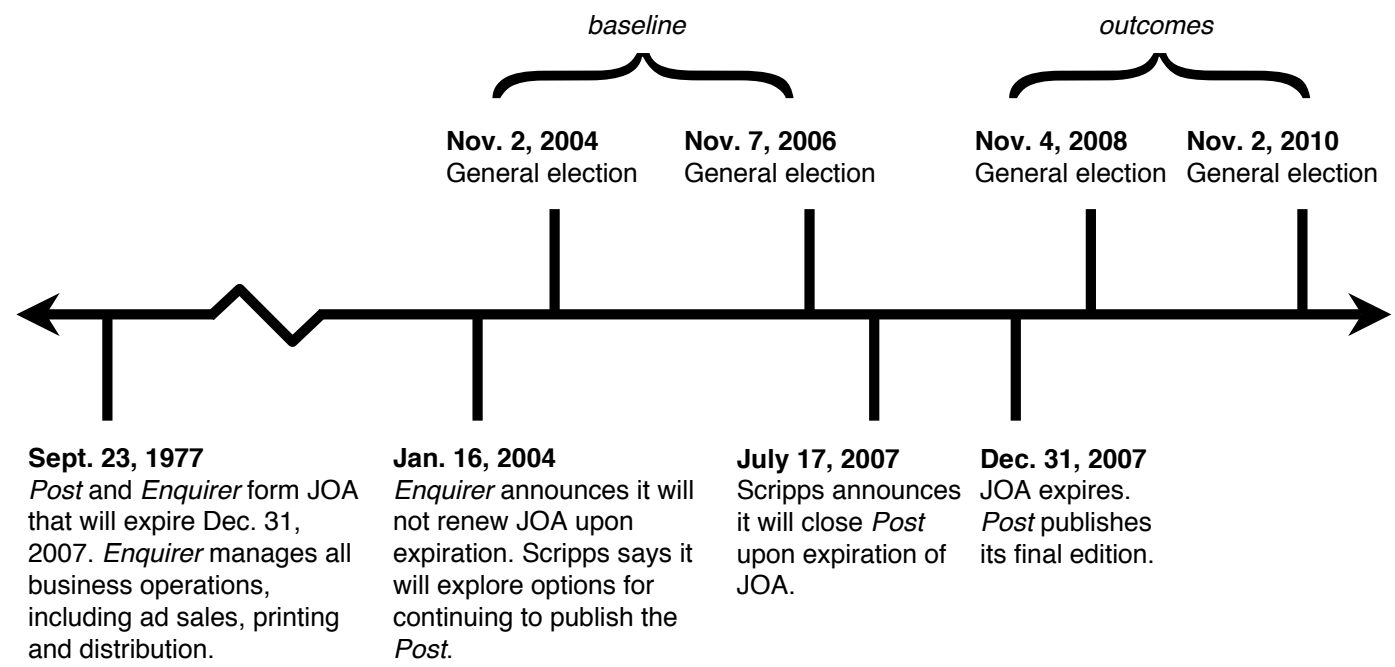

Figure 1: Key events for the empirical strategy.

sidy for newspaper competition. Under the Newspaper Preservation Act (1970), competing newspapers that are in "economic distress" can obtain an exemption from antitrust laws and form a joint operating agreement (JOA) that charges monopoly prices for subscriptions and advertising, as long as the papers retain independent newsrooms. The Post and the Enquirer formed a JOA in 1977. In passing the act, Congress determined that the value for democracy of preserving independent editorial voices outweighed the potential deadweight losses from monopoly pricing. ${ }^{6}$ As then-Rep. Spark Matsunaga, Democrat of Hawaii and a sponsor of the act, put it in House debate: "Let us make no mistake about it, we are here being forced into making a choice between preserving a free press as opposed to keeping the sanctity of the antitrust laws. In a democratic society such as ours the choice is obvious - the free press must be preserved" (Matsunaga, 1970). Despite the explicit congressional rationale for the Newspaper Preservation Act, and even though 27 JOAs have existed over the years, ours is the first analysis we know of to measure the political impact of preserving competition through a JOA. ${ }^{7}$

total Monday-to-Friday circulation of 246,323 in 1977. The decline was linear with time. The Enquirer's weekday circulation in 1977 was 190,407.

${ }^{6}$ Newspapers in a JOA also combine their printing and delivery operations to exploit economies of scale, but publishers can obtain these savings without an antitrust exemption so long as they continue to compete in advertising and subscription sales.

${ }^{7}$ An existing literature investigates the effect of JOAs on newspaper content and profits (see, e.g., Busterna and Picard, 1993). 
The JOA between the Post and the Enquirer is central to our empirical strategy. Figure 1 lays out the timeline of events. Like most JOAs, the Cincinnati agreement specified a terminal date, in this case Dec. 31, 2007. Unusually, though, the Post survived exactly until this date chosen 30 years in advance, and no longer. (Of the 21 other JOAs that have ended so far, 17 ended early when the owners decided that publishing two newspapers was unprofitable and closed one paper or merged the two papers together. The other four lapsed or were dissolved with both newspapers continuing to publish.) The Enquirer's owner, Gannett Co., announced in January 2004 that it would not renew the agreement at the terminal date, suggesting that Gannett thought publishing two newspapers no longer maximized joint surplus. (If Gannett had merely thought that profits from going it alone would exceed its share of JOA profits, it could have tried to renegotiate the agreement.) But the E.W. Scripps Co., owner of the Post, apparently preferred to keep publishing: Instead of agreeing with its partner to close the Post before the end of the JOA, as has been typical in other cities, ${ }^{8}$ Scripps said it would explore "whatever options it may have to continue publishing newspapers in the Cincinnati market in some form" (E.W. Scripps, 2004). These options proved unattractive because, with the Enquirer managing the JOA's business operations, Scripps would have had to buy printing presses and hire advertising and circulation salespeople to keep the Post open. Still, Scripps took more than three years to announce that it would close the paper (E.W. Scripps, 2007).

The Post's central role in Scripps' history may have motivated the company's reluctance. Company namesake Edward Willis Scripps made his reputation in the 1880s when he bought the Post and built it into what was, at the time, Ohio's largest daily (Baldasty, 1999; Stevens, 1968). The family-controlled media chain's headquarters remain in Cincinnati, and many corporate executives once worked in the Post newsroom. But even if Scripps' decision has an explanation other than historical sentiment, it seems unlikely that Scripps chose the Post's exact closing date near the actual time of the closing. ${ }^{9}$ Rather, the JOA partners picked a date 30 years in advance, and the Post closed on that date because it was the default

\footnotetext{
${ }^{8}$ Full disclosure: The first author worked from 1998 to 1999 at the Birmingham (Ala.) Post-Herald, a Scripps newspaper that participated in a JOA and later closed.

${ }^{9}$ Scripps has not publicly explained the timing of its decision to close the Post.
} 
outcome if the partners never changed the agreement.

Because the Post's closing date was fixed so far in advance, changes in local politics after early 2004 — when Gannett announced it would not renew the JOA — cannot have caused the paper to close exactly when it did. Third factors such as short-run municipalitylevel economic fluctuations that might affect both local politics and the paper's viability are also less likely to be responsible for the timing of the closing, though Scripps perhaps would have kept the paper open if the towns it covered had experienced a sudden economic boom. Therefore, we can more plausibly attribute changes in political outcomes after the Post closed to the paper's closing instead of some other source. To help rule out the possibility that the political changes occurred for other reasons and only randomly coincided with the Post's closure, we employ a difference-in-differences strategy, comparing changes in political outcomes before and after the closure in suburbs that received relatively more or less coverage from the paper. Suburbs that received less coverage serve as controls representing the likely change over time if the Post had never existed. We also account for the possibility that political outcomes and Post coverage both responded to the 2004 announcement on the paper's future by instrumenting for post-2004 coverage with 2003 coverage.

Many previous researchers have also studied newspapers' political impact. Most closely related are studies measuring the effect of newspapers' existence. Gentzkow et al. (forthcoming) analyze historical data from 1869 to 2004, with a particular focus on the 1869-1928 period, and show that the presence of a local daily newspaper raised presidential and congressional election turnout. Trounstine (2009) finds that incumbent advantage in city council elections is lower in cities with their own daily or weekly papers. Oberholzer-Gee and Waldfogel (2005) show that blacks are more likely to vote in areas that have black-targeted weekly papers. George and Waldfogel $(2006,2008)$ show that competition from The New York Times reduces local papers' circulation among highly educated readers and makes those readers less likely to vote. Adserà et al. (2003) show that states and countries with higher newspaper circulation per capita have less corruption. Mondak (1995) finds that voters in Pittsburgh saw themselves as less informed about local elections during a newspaper strike. More broadly, Gentzkow (2006) studies the effect of television on voter turnout, while Erikson (1976), Gerber et al. (2009), Kahn and Kenney (2002), Chiang and Knight (forthcoming), Snyder and 
Strömberg (2010), and others measure the effect of newspapers' content on voters' and politicians' preferences and behavior, taking newspapers' existence as given.

Our contribution to the literature is twofold. First, nearly all previous studies — like our study — use observational data, ${ }^{10}$ but even the most sophisticated observational studies run the risk that correlations between newspapers and political outcomes do not reflect a causal impact of newspapers: Unobserved and uncontrolled-for third factors may influence both newspapers and politics, or causality may run from politics to newspapers' content and availability rather than vice versa. In our case, the Post's predetermined closing date reduces such concerns, though at the cost of limiting the analysis to a small number of municipalities in just one state. Second, the market for news media is changing rapidly with the rise of the Internet. Our data, more recent than those in other papers, show that newspapers' impact persists in the present-day market environment.

The paper proceeds as follows. Section 2 summarizes our data, section 3 lays out our empirical strategy and results, and section 4 concludes.

\section{Data}

Our analysis covers all 48 incorporated municipalities in seven Kentucky counties: Boone, Campbell, and Kenton, which formed the core of the Post's Kentucky circulation area, as well as Bracken, Gallatin, Grant, and Pendleton, which border the core counties. ${ }^{11}$ We have data on the number of stories about each municipality in both the Post and the Enquirer in each year from 2003 to 2007, as well as the number of stories in the Enquirer in 2008, 2009, and 2010; the results of every school board, city council, and city commission election from 2004 to $2010^{12}$; candidates' campaign spending in each election; and demographics from the 2000 census.

\footnotetext{
${ }^{10}$ The main experimental study is Gerber et al., which uses a randomized controlled trial to measure the effect of receiving a newspaper subscription. However, the impact of receiving a newspaper can differ from the impact of the newspaper's existence if readers tell nonreaders about stories or if politicians behave differently when a newspaper might write about them.

${ }^{11}$ Our sample excludes the former city of Latonia Lakes, Kenton County, which was dissolved in 2006.

${ }^{12}$ We exclude mayoral elections because only three municipalities in our sample held mayoral elections in 2008.
} 


\section{A. Newspaper coverage}

We use the 2003 to 2007 Post and Enquirer story counts to construct an index of the Post's importance in covering each municipality: the fraction of stories about that municipality that appeared in the Post. This index is a useful measure of the Post's role because, all else equal, communities where the Post's share of coverage was higher lost more coverage when the Post closed. (We cannot base our analysis on circulation data because independent dealers delivered the Post and the paper had no centralized list of subscribers' addresses. We also cannot use the Audit Bureau of Circulations' zip-code-level data because some towns in our sample share zip codes. Regardless, because broadcasters and bloggers often quote newspaper stories, the number of stories a paper publishes may matter more than the number of subscribers: One subscriber with a well-read blog or popular broadcast can multiply a story's impact many times. Such repetition may help explain how the Post could have a meaningful political impact despite its low circulation.) The Post's share of coverage is highly serially correlated: $R$-squareds in regressions of 2004 through 2007 indexes on the 2003 index range from 0.71 to 0.83 . Thus the index measures relatively permanent differences in the Post's importance across municipalities.

We obtain the 2003 to 2007 story counts by searching the widely used NewsLibrary database. ${ }^{13}$ We include the county name as well as the municipality name in the searches to avoid counting irrelevant stories that would otherwise appear for municipalities with generic names such as Union. To see whether certain kinds of stories disproportionately include the county name, we picked two municipalities at random and performed searches with and without their respective county names. We found no salient differences in the content of stories with and without county names. We also found that the searches with county names returned very few irrelevant stories.

The Post published both an Ohio edition and a Kentucky edition, with some stories appearing in both editions. In general, the Kentucky edition provides a more accurate measure of coverage in Kentucky. However, every Kentucky-edition story appears in our searches for the city of Covington because the Post's Kentucky reporters were based there. Therefore, for all municipalities except Covington, we count stories in the Kentucky edition. For

\footnotetext{
${ }^{13}$ http: //www.newslibrary.com
} 
Covington, we count stories in the Ohio edition and multiply by that year's average ratio in other municipalities of Kentucky-edition stories to Ohio-edition stories. (This ratio ranges from 6 to 10.)

We also counted stories in the Enquirer in 2008, 2009, and 2010 to investigate whether it changed its product positioning after the Post's exit: If the Enquirer added coverage in an effort to capture the Post's former readers, it could have offset the loss of the Post's coverage. We could not obtain the 2008-2010 story counts from NewsLibrary because the Enquirer removed all its stories from NewsLibrary in early 2009 and switched to a competing archive service, ProQuest Archiver. ${ }^{14}$ Story counts in ProQuest are not directly comparable to those in NewsLibrary because ProQuest includes much material that does not appear in NewsLibrary and does not represent actual coverage by the newspaper, such as death announcements submitted by funeral homes and event listings. We excluded the death announcements from our ProQuest searches but could not find an efficient way to exclude other material. (ProQuest's charges for viewing full articles prohibited us from examining each story to determine whether to exclude it.) When we regress the ProQuest story count for each community in 2006 on the NewsLibrary count for that year, we obtain a statistically insignificant intercept of 14, a highly significant slope of 5.6, and an $R$-squared of 0.82 , suggesting that ProQuest story counts are a multiple of NewsLibrary counts plus random error. We therefore think comparisons of ProQuest counts in 2008-2010 vs. 2006 (the last full year before the Post's closing was confirmed) are useful for examining changes in the Enquirer's coverage. We prefer not to use the ProQuest counts for our main analysis both because irrelevant results inflate the ProQuest counts and because ProQuest does not index Post stories.

\section{B. Political outcomes}

News coverage potentially influences election outcomes in many ways. By revealing incumbents' misdeeds or making it easier for challengers to get their message out, a newspaper may reduce incumbent advantage (Trounstine, 2009). Alternatively, if newspaper stories increase incumbents' name recognition (Snyder and Strömberg, 2010), then a newspaper

\footnotetext{
${ }^{14}$ http://pqasb.pqarchiver. com/enquirer/search.html
} 
could increase incumbent advantage. Newspaper stories could also raise interest in politics or make citizens feel more connected to their communities, thus inspiring more people to vote or run for office. In addition, the closure of a newspaper could change campaign spending. Candidates may spend less if reduced competition lowers the need to advertise, or spend more if they must use paid ads to substitute for the free newspaper coverage they received previously. ${ }^{15}$

To measure these aspects of political engagement and competition, we obtained election records for 2004 through 2010 for every municipality in the counties of interest. ${ }^{16}$ Kentucky holds all regular municipal and school board general elections in November of evennumbered years, simultaneously with elections for president, Congress, and state legislature (but not for state executive offices, which are elected in odd-numbered years). The records include the date of the election; the election type (general or primary, although only two municipalities in our sample hold primaries); the name of the municipal body (for instance, City of Bromley or Covington Independent School District); the title of the elected office (for instance, city council member); the candidates' names and party affiliations (however, virtually all candidates are nonpartisan); the number of votes each candidate received; the identities of the winners; and the number of votes each voter could cast (some elections allow voters to cast multiple votes, corresponding to multiple seats). We also obtained records of each candidate's campaign spending from the Kentucky Registry of Election Finance.

We use the election dataset to construct several measures of political engagement and competition. Our first measure is an estimate of voter turnout. Ideally, we would measure turnout in elections with only local races on the ballot, but we cannot do so because regular municipal elections in Kentucky are always simultaneous with national elections. Instead, we estimate the number of people who voted in each municipality's local races in the 2004, 2006, 2008, and 2010 general elections. This approach helps us to measure citizens' engagement

\footnotetext{
${ }^{15}$ Many other outcomes are also potentially of interest but would be difficult to study in the context of Kentucky municipal elections. For example, we cannot study party affiliation, because nearly all candidates are nonpartisan. We also cannot study victory margins, because most races involve multiple candidates competing for multiple seats, with voters allowed to cast multiple votes, so that strategic voting is possible and vote totals do not necessarily reflect the strength of voters' preferences.

${ }^{16}$ We obtained the 2004 through 2008 records by contacting county election supervisors and downloaded the 2010 records from the Kentucky State Board of Elections (http://www.elect.ky.gov/results). The elections board Web site does not provide municipal election results before 2010 .
} 
with local elections because people who vote for national but not for local offices will not affect our estimate of local voters. (People who vote for local offices but would not have come to the polls without a national election can still influence our results, however. For this reason, our empirical analysis controls for whether the election took place in a presidential election year.) Because election records do not show the actual number of voters in a given race, we construct our estimate of the number of local voters in two steps. For each local race on the ballot, we estimate the number of voters casting ballots in that race as the larger of the most votes received by any candidate or the ratio of total votes cast to the number of votes allowed per voter in that race. We then estimate the number of voters in all local races by the maximum across races of the number of voters in each race. There is no municipal-level data on voting-age population after 2000 for the small suburbs in our sample, so we use the number of voters as a proxy for turnout rates.

Our second measure is the ratio of candidates for local office to seats up for election. For each municipality and year, we count the people whose names appeared on a primary or general election ballot. We divide this number by the number of seats up for election.

Our third measure is the fraction of seats in a municipality that incumbents win in a given year. We measure incumbent advantage by the fraction of seats won by incumbents rather than by the difference in probabilities of winning for nonincumbents and incumbents conditional on running because unpopular incumbents might not seek reelection. In that case, incumbents who appeared on the ballot would have a high probability of winning even if voters were, in effect, throwing out many other incumbents. Election records do not identify incumbents, so we determine whether a candidate is an incumbent by checking whether that candidate won the previous election for the same office. We verified a random sample of the results by contacting officeholders and found that our method was accurate. Because our election data start in 2004, this method allows us to identify incumbents starting in 2006 for city council and city commission seats, which have two-year terms. We do not examine incumbent advantage in school board elections, because these elections are for four-year terms and our data would allow us to identify school board incumbency starting only in 2008, after the Post closed.

Our fourth measure is campaign spending per candidate: the total campaign spending 
Table 1: Summary statistics: baseline characteristics ( $N=48$ municipalities).

\begin{tabular}{lrrrr}
\hline Variable & mean & s.d. & $\min$ & $\max$ \\
\hline Demographics (2000 census) & & & & \\
$\quad$ Voting-age population & 3,959 & 5,728 & 55 & 32,151 \\
$\quad$ Voting-age percent black & 1.2 & 1.7 & 0.0 & 8.8 \\
$\quad$ Voting-age percent ages 18-34 & 31.9 & 5.7 & 21.1 & 50.0 \\
Enquirer articles (NewsLibrary) & & & & \\
2003 & 37.1 & 38.7 & 1 & 154 \\
2004 & 36.2 & 40.9 & 0 & 163 \\
2005 & 31.1 & 36.2 & 0 & 136 \\
2006 & 24.4 & 28.2 & 0 & 128 \\
2007 & 19.2 & 22.3 & 0 & 99 \\
Post articles (NewsLibrary) & & & & \\
2003 & 173.3 & 208.0 & 7 & 1,310 \\
2004 & 200.2 & 220.3 & 14 & 1,361 \\
2005 & 176.1 & 191.5 & 7 & 1,140 \\
2006 & 160.6 & 198.1 & 8 & 1,270 \\
2007 & 151.9 & 199.9 & 3 & 1,311 \\
Post share & & & & \\
2003 & 0.82 & 0.11 & 0.33 & 0.97 \\
2004 & 0.86 & 0.09 & 0.55 & 1.00 \\
2005 & 0.86 & 0.09 & 0.52 & 1.00 \\
2006 & 0.87 & 0.11 & 0.47 & 1.00 \\
2007 & 0.87 & 0.12 & 0.27 & 1.00 \\
average, 2004-2007 & 0.87 & 0.10 & 0.45 & 0.99 \\
\hline
\end{tabular}

recorded in the election finance registry for all school board, council, and commission candidates in a municipality in a given year, divided by the number of candidates. We deflate the data to constant dollars using the Consumer Price Index.

\section{Describing the data}

Table 1 summarizes the baseline data on demographics and news coverage. The municipalities range in size from California, voting-age population 55 in 2000, to Covington, voting-age population 32,151. The Post dominated coverage of the Kentucky suburbs, publishing 82 to 87 percent of total stories in each year. But the Post's importance varied substantially across municipalities, with the two papers splitting coverage of some places roughly equally and the Post publishing 100 percent of stories about other places.

Table 2 reports descriptive statistics on the outcomes we examine. No clear patterns are evident over time, except that the Enquirer's overall level of coverage of the Kentucky 
Table 2: Summary statistics: outcomes $(N=48 \mathrm{mu}-$ nicipalities).

\begin{tabular}{|c|c|c|c|c|}
\hline Variable & mean & s.d. & $\min$ & $\max$ \\
\hline \multicolumn{5}{|c|}{ City council, city commission races } \\
\hline \multicolumn{5}{|c|}{ Fraction of seats won by incumbent } \\
\hline 2006 & 0.63 & 0.21 & 0.00 & 1.00 \\
\hline 2008 & 0.73 & 0.18 & 0.33 & 1.00 \\
\hline 2010 & 0.65 & 0.22 & 0.17 & 1.00 \\
\hline \multirow{2}{*}{\multicolumn{5}{|c|}{$\begin{array}{l}\text { School board, city council, city commission races } \\
\text { Ratio of candidates to seats }\end{array}$}} \\
\hline & & & & \\
\hline 2004 & 1.41 & 0.39 & 1 & 2.83 \\
\hline 2006 & 1.27 & 0.34 & 1 & 2.57 \\
\hline 2008 & 1.36 & 0.38 & 1 & 2.71 \\
\hline 2010 & 1.33 & 0.43 & 0.5 & 3.00 \\
\hline \multicolumn{5}{|c|}{ Estimated number of voters } \\
\hline 2004 & 1,610 & 1,995 & 20 & 9,273 \\
\hline 2006 & 1,129 & 1,342 & 5 & 6,296 \\
\hline 2008 & 1,700 & 2,106 & 29 & 9,203 \\
\hline 2010 & 1,173 & 1,376 & 11 & 5,580 \\
\hline \multicolumn{5}{|c|}{ Spending per candidate (in 2004 dollars) } \\
\hline 2004 & 303 & 1475 & 0 & 10,051 \\
\hline 2006 & 243 & 1,189 & 0 & 8,117 \\
\hline 2008 & 241 & 900 & 0 & 5,746 \\
\hline 2010 & 287 & 1,369 & 0 & 9,233 \\
\hline & & & News & overage \\
\hline \multicolumn{5}{|c|}{ Enquirer articles (ProQuest) } \\
\hline 2006 & 151.3 & 175.0 & 3 & 826 \\
\hline 2008 & 148.5 & 158.9 & 0 & 758 \\
\hline 2010 & 58.3 & 75.8 & 0 & 400 \\
\hline
\end{tabular}


suburbs remained stable in the first year after the Post closed and then fell dramatically. However, other factors may also have changed from year to year - for example, the 2008 presidential election had unusually high turnout - and influenced election outcomes or Enquirer coverage. Our task in the next section is to examine how the Post's closure affected outcomes, holding other factors constant.

\section{Empirical strategy and results}

Our basic model for the effect of Post coverage on an outcome $y_{i t}$ in municipality $i$ in year $t$ is

$$
y_{i t}=\alpha_{i}+\theta_{0, t}+\mathbf{x}_{i}^{\prime} \boldsymbol{\theta}_{2, t}+\theta_{1} \text { Post_Share }_{i} \times \text { Post_Closed }_{t}+\epsilon_{i t},
$$

where Post_Share $i$ is the Post's share of all stories about community $i$ in the period before the Post shut down; Post_Closed $t_{t}$ is an indicator for whether the Post had closed as of date $t ; \mathbf{x}_{i}$ represents demographic characteristics of the municipality; and $\epsilon_{i t}$ is all factors other than postshare that affect the outcome. The coefficient $\theta_{1}$ is the effect of closing the Post on outcome $y$ in a community that received all its news coverage from the Post; a positive value of $\theta_{1}$ implies that closing the Post raised outcome $y$ in communities where the Post provided a large share of coverage, compared with communities where the Post provided less coverage.

We use the Post's share of stories instead of the total number of stories in the Post as our measure of the Post's importance in covering a municipality because larger municipalities may tend to have more stories in both newspapers. Taking the ratio of stories in the two papers controls for the overall level of coverage while limiting the number of regressors, which is desirable because we have data on only 48 municipalities. We calculate Post_Share ${ }_{i}$ as the average over 2004-2007 of the Post's share of stories in each year. Averaging helps to remove year-to-year fluctuations that might result from random news events but do not reflect true changes in the Post's importance for a community. In addition, averaging guarantees that we use the same measure of the Post's importance for all years that it was open, so we are identifying the effect of the paper's closing rather than the effect of short-run fluctuations in Post and Enquirer coverage while both papers were open.

Our model controls for a variety of factors other than Post coverage that could affect election outcomes. The municipality fixed effects $\alpha_{i}$ account for time-invariant unobservable 
differences across municipalities, such as permanent differences in voters' interest in politics. The year fixed effects $\theta_{0, t}$ account for unobservable differences across years that affect all municipalities equally, such as any national political events that have the same influence on all voters. Finally, the interaction of year effects with demographics $\mathbf{x}_{i}^{\prime} \boldsymbol{\theta}_{2, t}$ accounts for differences in how national events affect places with different observable demographics.

To understand how equation (1) identifies the Post's effect on elections, it is useful to consider what would happen if we had only two years of data - 2004 and 2008, say. In that case, we could estimate equation (1) by taking first differences. If we subtract equation (1) for 2004 from the same equation for 2008, we obtain

$$
y_{i, 2008}-y_{i, 2004}=\theta_{0,2008}-\theta_{0,2004}+\mathbf{x}_{i}^{\prime}\left(\boldsymbol{\theta}_{2,2008}-\boldsymbol{\theta}_{2,2004}\right)+\theta_{1} \text { Post_Share }_{i}+\left(\epsilon_{i, 2008}-\epsilon_{i, 2004}\right) .
$$

Equation $\left(1^{\prime}\right)$ represents a difference-in-differences strategy: It compares changes in outcomes across years in municipalities with different levels of pre-shutdown Post coverage. In practice, we have four elections' worth of data, so we estimate (1) rather than $\left(1^{\prime}\right)$, but the intuition from $\left(1^{\prime}\right)$ remains: We identify the effect of the Post by comparing how outcomes changed over time in municipalities that, before the closing, received different amounts of coverage from the paper.

Equation $\left(1^{\prime}\right)$ also gives intuition into what factors might bias our results. The error term in $\left(1^{\prime}\right)$ is $\left(\epsilon_{i, 2008}-\epsilon_{i, 2004}\right)$. Hence ordinary least squares estimates of $\theta_{1}$ based on $\left(1^{\prime}\right)$ - and fixed-effects estimates based on (1) — will be biased if changes in other factors $\left(\epsilon_{i, 2008}-\epsilon_{i, 2004}\right)$ are correlated with the initial level of Post coverage. The fact that the Post's closing date was set 30 years in advance helps rule out many sources of correlation. For example, if Scripps had chosen the closing date based on economic trends around 2007 in the communities where the Post was strong, and if local economic trends were correlated with local political trends, then the error term would be correlated with the Post's share in 2004. Because Scripps appears not to have set the closing date based on contemporaneous economic trends, we think this type of correlation is unlikely to be a problem.

Other sources of correlation may remain, however. Although the municipality fixed effects $\alpha_{i}$ and year fixed effects $\theta_{0, t}$ remove any permanent characteristics of municipalities 
and any differences between years that affected all municipalities equally, the municipality and year fixed effects cannot remove differences between the years that affected some municipalities more than others. Our leading concern is that Barack Obama's historic presidential candidacy in 2008 may have increased turnout among young or black voters. Kentucky and national exit polls show that blacks made up a larger fraction of voters in 2008 than in 2004. National polls also show a slight increase in turnout among the young, though Kentucky polls show no such difference. (See National Election Pool, 2004 and 2008. The polls show no other significant differences between the 2004 and 2008 electorates in Kentucky.) Exit polls do not break down data by municipality, but if the statewide and national differences carried through to the places we study, and if Post coverage varied with the age structure or racial composition of a community, ${ }^{17}$ then we might see outcomes change differentially in places that had high Post coverage even if Post coverage had no causal effect on turnout. We account for this possible correlation by including as demographic controls $\mathbf{x}_{i}$ in (1) the fraction of voting-age people who are black and the fraction who are ages 18 to 34 in the 2000 census. ${ }^{18}$ Since the coefficients $\boldsymbol{\theta}_{2, t}$ on the demographic variables are different for each year, the model allows events in a given year to have systematically different effects on municipalities with different demographics. Related studies such as Oberholzer-Gee and Waldfogel (2005) and George and Waldfogel (2008) also include jurisdiction and year effects and interactions of year effects with demographics to eliminate bias.

Some municipalities might also have unobservably different trends in factors that affect the outcomes we study - for example, population growth rates might vary across municipalities — and these differences might be correlated with Post coverage. Therefore, in some specifications, we control for this possibility by adding municipality-specific trends to the model:

$$
y_{i t}=\alpha_{i}+\theta_{0, t}+\beta_{i} \times t+\mathbf{x}_{i}^{\prime} \boldsymbol{\theta}_{2, t}+\theta_{1} \text { Post_Share }_{i} \times \text { Post_Closed }_{t}+\epsilon_{i t} .
$$

Another concern is that any unobserved factor $\epsilon_{i, 2004}$ that affected politics in 2004 could

\footnotetext{
${ }^{17}$ We find marginally statistically significant evidence that the Post's share was higher in communities where a larger share of the voting-age population is black or ages 18 to 34 .

${ }^{18}$ We measure the fraction who are ages 18 to 34 as of 2000 , rather than the fraction who will reach ages 18 to 34 by 2008 , because the number of teenagers in 2000 will be a poor predictor of the number of young adults in 2008 if different communities are particularly attractive to people of different ages.
} 
also have prompted the newspapers to change their coverage, again producing a correlation between the error term and the Post's coverage share in 2004. If political behavior and Post or Enquirer content both changed after 2004 in anticipation of the JOA's end, we could also find a spurious correlation. To guard against these possibilities, in some specifications we instrument for Post_Share ${ }_{i}$, which is the Post's average share over 2004-2007, with its 2003 share. The 2003 share will be uncorrelated with $\epsilon_{i, 2004}$ if the errors are serially uncorrelated. Instrumenting for the Post's share can also reduce attenuation bias in the estimate of $\theta_{1}$ if the Post's share in any given year is a noisy measurement of the paper's true long-run importance in a community. ${ }^{19}$

We weight all of our estimates by the municipality's voting-age population (measured in 2000). There are both statistical and policy grounds for weighting. From a statistical perspective, all of our outcomes except number of voters are averages, so random fluctuations in outcomes will likely be larger in smaller municipalities, and the efficient estimator will weight by population. From a policy perspective, policy-makers may care more about outcomes in places where more people live. The appendix shows that - except in a few cases that we highlight below - our qualitative results are robust to calculating the estimates without weights. ${ }^{20}$

Table 3 presents the results. On all four measures of political engagement and competition, we find indications that the Post's closure made elections less competitive:

Number of voters: In all specifications, our estimates show that relatively fewer people went to the polls after the Post closed in places where the Post was more important. The point estimates are large: The Post's closing is estimated to reduce the number of voters by between 59 percent $\left(1-e^{-0.88}\right)$ and 92 percent $\left(1-e^{-2.55}\right)$ in a municipality where

\footnotetext{
${ }^{19}$ The measurement error in the Post's share appears to be classical: If postshare ${ }_{i t}$ is the Post's share in community $i$ in year $t$, we find that $\operatorname{corr}\left(\right.$ postshare $_{i t}$, postshare $\left._{i s}\right)$ does not depend on $t-s$ for $t \neq s$, consistent with a model where postshare $_{i t}=$ trueshare $_{i}+u_{i t}$ with i.i.d. $u_{i t}$.

${ }^{20} \mathrm{In}$ an earlier version of this paper that examined only the short-run impact of the Post's closing, we also considered specifications that accounted for the limited range of the dependent variables. (For example, campaign spending is left-censored at zero, and no matter how big or small incumbents' advantage is, the probability of an incumbent victory cannot exceed one or fall below zero.) We found that the results were generally similar to those obtained with ordinary least squares estimation of (1). However, the limiteddependent-variable estimators do not let us use an instrument for Post_Share ${ }_{i}$, so we do not employ them in this version.
} 
Table 3: Effect of the Post on political engagement and competition.

\begin{tabular}{|c|c|c|c|c|c|c|c|c|}
\hline \multirow[b]{3}{*}{ Post share $\times$ Post closed } & \multicolumn{4}{|c|}{ Ordinary least squares } & \multicolumn{4}{|c|}{ Instrumental variables } \\
\hline & \multicolumn{8}{|c|}{ A. $\ln$ (voters in general election) } \\
\hline & $\begin{array}{l}-1.07 \\
(0.33)\end{array}$ & $\begin{array}{l}-0.88 \\
(0.32)\end{array}$ & $\begin{array}{l}-1.43 \\
(1.33)\end{array}$ & $\begin{array}{l}-1.57 \\
(1.30)\end{array}$ & $\begin{array}{l}-1.18 \\
(0.38)\end{array}$ & $\begin{array}{l}-0.90 \\
(0.34)\end{array}$ & $\begin{array}{l}-1.76 \\
(1.01)\end{array}$ & $\begin{array}{l}-2.55 \\
(0.97)\end{array}$ \\
\hline$R$-squared & 0.99 & 0.99 & 0.99 & 0.99 & 0.99 & 0.99 & 0.99 & 0.99 \\
\hline \multirow[t]{2}{*}{ observations } & 192 & 192 & 192 & 192 & 192 & 192 & 192 & 192 \\
\hline & \multicolumn{8}{|c|}{ B. ratio of candidates to seats } \\
\hline Post share $\times$ Post closed & $\begin{array}{l}-0.59 \\
(1.00)\end{array}$ & $\begin{array}{l}-1.13 \\
(0.81)\end{array}$ & $\begin{array}{l}-1.57 \\
(2.70)\end{array}$ & $\begin{array}{l}-0.81 \\
(2.70)\end{array}$ & $\begin{array}{l}-0.29 \\
(1.15)\end{array}$ & $\begin{array}{l}-0.97 \\
(0.65)\end{array}$ & $\begin{array}{l}-3.53 \\
(1.76)\end{array}$ & $\begin{array}{l}-2.75 \\
(1.70)\end{array}$ \\
\hline$R$-squared & 0.87 & 0.89 & 0.93 & 0.93 & 0.87 & 0.89 & 0.93 & 0.93 \\
\hline \multirow[t]{2}{*}{ observations } & 192 & 192 & 192 & 192 & 192 & 192 & 192 & 192 \\
\hline & \multicolumn{8}{|c|}{ C. probability that winner is incumbent } \\
\hline Post share $\times$ Post closed & $\begin{array}{c}0.97 \\
(0.74)\end{array}$ & $\begin{array}{c}0.88 \\
(0.81)\end{array}$ & $\begin{array}{c}2.88 \\
(2.44)\end{array}$ & $\begin{array}{c}2.75 \\
(2.47)\end{array}$ & $\begin{array}{c}0.86 \\
(0.63)\end{array}$ & $\begin{array}{c}0.70 \\
(0.71)\end{array}$ & $\begin{array}{c}4.15 \\
(1.58)\end{array}$ & $\begin{array}{c}3.62 \\
(1.32)\end{array}$ \\
\hline$R$-squared & 0.35 & 0.38 & 0.72 & 0.74 & 0.35 & 0.38 & 0.71 & 0.73 \\
\hline \multirow[t]{2}{*}{ observations } & 144 & 144 & 144 & 144 & 144 & 144 & 144 & 144 \\
\hline & \multicolumn{8}{|c|}{ D. campaign spending per candidate (\$) } \\
\hline Post share $\times$ Post closed & $\begin{array}{l}-4473 \\
(3932)\end{array}$ & $\begin{array}{l}-1772 \\
(1781)\end{array}$ & $\begin{array}{l}-8547 \\
(9627)\end{array}$ & $\begin{array}{l}-2819 \\
(3919)\end{array}$ & $\begin{array}{l}-7320 \\
(4842)\end{array}$ & $\begin{array}{l}-2614 \\
(1513)\end{array}$ & $\begin{array}{r}-14689 \\
(9629)\end{array}$ & $\begin{array}{l}-4864 \\
(2794)\end{array}$ \\
\hline$R$-squared & 0.96 & 0.99 & 0.97 & 0.99 & 0.96 & 0.99 & 0.97 & 0.99 \\
\hline observations & 192 & 192 & 192 & 192 & 192 & 192 & 192 & 192 \\
\hline municipalities & 48 & 48 & 48 & 48 & 48 & 48 & 48 & 48 \\
\hline demographic controls & $\mathrm{N}$ & $\mathrm{Y}$ & $\mathrm{N}$ & $\mathrm{Y}$ & $\mathrm{N}$ & $\mathrm{Y}$ & $\mathrm{N}$ & $\mathrm{Y}$ \\
\hline municipality-specific trends & $\mathrm{N}$ & $\mathrm{N}$ & $\mathrm{Y}$ & $\mathrm{Y}$ & $\mathrm{N}$ & $\mathrm{N}$ & $\mathrm{Y}$ & $\mathrm{Y}$ \\
\hline
\end{tabular}

Standard errors clustered by municipality in parentheses. Estimates weighted by population age 18 and older in 2000 census. Panels A, B, and D use data from 2004, 2006, 2008, and 2010; panel C uses data from 2006, 2008, and 2010. Post share is average over 2004-2007 of the Post's share of stories in each year, with the 2003 share used as an instrument for instrumental variables estimates. All specifications include municipality and year fixed effects. Demographic controls are percentage of the population age 18 and older who are black and who are ages 18 to 34 and are interacted with year indicator variables. 
the Post provided all coverage, compared with a municipality where the Post provided no coverage. Notice, though, that the range of Post_Share is substantially smaller than zero to one. Our estimates will not reflect nonlinearities in the effect of Post_Share outside the observed range. The standard deviation of Post_Share is 0.10 ; thus, for each one-standard-deviation increase in the Post's share of coverage, the Post's closing reduced the number of voters by between 8.4 percent $\left(1-e^{-0.88 \times 0.1}\right)$ and 22.5 percent $\left(1-e^{-2.55 \times 0.1}\right)$. Because our dependent variable is the natural logarithm of the number of voters, we can interpret our results as describing the effect on turnout rates: Changes in the voting-age population, which is unobserved but is the denominator of the turnout rate, will enter the error term of (1), and our estimates will be unbiased if the population growth rate is uncorrelated with the Post's coverage share. ${ }^{21}$ The effect is statistically significant at least at the 5 percent level in both OLS and IV specifications when we do not include municipality-specific trends. Controlling for municipality-specific trends makes both the point estimates and standard errors larger, so that the effect is not always statistically significant. The appendix shows that we obtain similar results, slightly smaller in magnitude but with larger standard errors, when we do not weight by population.

Number of candidates: Relatively fewer people ran for office after the Post closed in places where the Post was more important. According to the estimates that do not control for municipality-specific trends, for each one-standard-deviation increase in the Post's share, the paper's closing reduced the ratio of candidates to seats by between 0.03 and 0.11. In most specifications, the effect is not statistically significant at conventional levels. The appendix shows that the estimated effect is smaller but still negative when we do not weight by population.

Incumbent advantage: Incumbent advantage rose after the Post closed in places where the Post was more important. According to the estimates that do not control for municipality-specific trends, for each one-standard-deviation increase in the Post's

\footnotetext{
${ }^{21}$ We cannot check this assumption about population growth because the Census Bureau has no population counts after 2000 for communities as small as those we study.
} 
share, the paper's closing raised incumbent advantage by between 7 and 10 percentage points. The point estimates are generally slightly larger than the standard errors but are not statistically significant. This is the sole outcome for which the choice of weights matters for our qualitative results: The appendix shows that if we do not weight by population, then the Post's closing reduced incumbent advantage.

Campaign spending: Candidates spent relatively less money on their campaigns after the Post closed in places where the newspaper was more important. For each one-standarddeviation increase in the Post's share, the paper's closing reduced spending by between $\$ 177$ and $\$ 1,469$ per candidate. The result suggests that the lower need for spending in less-competitive elections outweighed the potential need to buy campaign ads to replace newspaper coverage. The estimated effect is surprisingly large relative to average spending, but because average spending includes many candidates who spent no money, the estimated effect is more plausible compared with the average spending of candidates who reported positive spending. As with the other outcomes, the largest point estimates come when we control for municipality-specific trends. The point estimates are usually larger than the standard errors but not statistically significant. The appendix shows that the estimated effect is an order of magnitude smaller, but still negative, when we do not weight by population. In regressions not reported here, we also found a consistently negative effect of the Post's closure on spending when the dependent variable was total spending or the natural logarithm of spending.

Controlling for race and age structure proves not to affect the qualitative results, though the magnitudes of the coefficients change in some cases. In regressions not reported here, we obtained similar results when we controlled only for race and when we controlled for adult population in addition to race and age structure. The small sample size makes the dangers of specification searching particularly high, so we deliberately did not experiment with other controls. For all outcomes, controlling for municipality-specific trends makes the estimated effects larger in magnitude; thus, our results are not driven by unobserved differences in trends between municipalities where the Post played a larger or smaller role.

The impact of the Post's closing could be larger in the short run than in the long 
run if it takes some time for other media to replace the Post's coverage. Our estimates of (1) would obscure this possibility by averaging together short-run outcomes from 2008 (less than a year after the paper closed) with long-run outcomes from 2010 (nearly three years after the closing). We investigate whether the short-run and long-run impacts are different by estimating an equation with separate short-run and long-run coefficients:

$$
\begin{aligned}
& y_{i t}=\alpha_{i}+\theta_{0, t}+\mathbf{x}_{i}^{\prime} \boldsymbol{\theta}_{2, t}+\theta_{1, S R} \text { Post_Share }_{i} \times \text { Post_Closed_SR }_{t} \\
& +\theta_{1, L R} \text { Post_Share }_{i} \times \text { Post_Closed_LR }_{t}+\epsilon_{i t} .
\end{aligned}
$$

In equation (3), Post_Closed_SR $R_{t}$ is 1 in 2008 and 0 otherwise, while Post_Closed_LR $R_{t}$ is 1 in 2010 and 0 otherwise. The coefficient $\theta_{1, S R}$ describes the impact of the Post's closing in the short run, 2008, while the coefficient $\theta_{1, L R}$ describes the impact in the long run, 2010. Note that if we include municipality-specific trends in (3), identification requires data on at least two years before the Post closed; thus, when we estimate (3), we cannot include municipality-specific trends for the incumbent-advantage outcome, for which we have data in only one pre-closing year.

Table 4 shows the results from estimating (3). In almost all specifications, the standard errors are large and we cannot reject the hypothesis that short-run and long-run effects are equal. However, some general patterns appear in the point estimates. When we examine the number of voters, the short-run and long-run effects of the Post's closing are similar; if anything, we estimate that the closing depressed turnout more in the long run than in the short run. For all other outcomes, however, the short-run effects are generally larger in magnitude than the long-run effects, and in a few specifications, the long-run effects change sign. The point estimates thus suggest that the Post's closing had a long-lived effect on voter turnout but that the impacts on the number of candidates, incumbent advantage, and campaign spending diminished with time.

In table 5, we use equation (3) to study how the Post's closure affected the Enquirer's coverage in the short run and the long run. Our dependent variable $y_{i t}$ is the ratio of Enquirer stories about municipality $i$ in year $t$ to Enquirer stories about municipality $i$ in 2006. (Thus $y_{i t}=1$ for all municipalities in 2006.) A 0.01-unit change in this variable reflects a 1 percent 
Table 4: Comparing short-run and long-run impacts of the Post's closing.

\begin{tabular}{|c|c|c|c|c|c|c|c|c|}
\hline \multirow[b]{3}{*}{ Post share $\times($ year $=2008)$} & \multicolumn{4}{|c|}{ Ordinary least squares } & \multicolumn{4}{|c|}{ Instrumental variables } \\
\hline & \multicolumn{8}{|c|}{ A. $\ln$ (voters in general election) } \\
\hline & $\begin{array}{l}-0.92 \\
(0.45)\end{array}$ & $\begin{array}{l}-0.85 \\
(0.47)\end{array}$ & $\begin{array}{l}-1.90 \\
(1.37)\end{array}$ & $\begin{array}{l}-1.99 \\
(1.40)\end{array}$ & $\begin{array}{l}-0.98 \\
(0.42)\end{array}$ & $\begin{array}{l}-1.02 \\
(0.44)\end{array}$ & $\begin{array}{l}-2.45 \\
(1.02)\end{array}$ & $\begin{array}{l}-3.14 \\
(1.08)\end{array}$ \\
\hline Post share $\times($ year $=2010)$ & $\begin{array}{l}-1.22 \\
(0.49)\end{array}$ & $\begin{array}{l}-0.92 \\
(0.40)\end{array}$ & $\begin{array}{l}-2.85 \\
(1.81)\end{array}$ & $\begin{array}{l}-2.83 \\
(1.96)\end{array}$ & $\begin{array}{l}-1.38 \\
(0.54)\end{array}$ & $\begin{array}{l}-0.79 \\
(0.38)\end{array}$ & $\begin{array}{l}-3.82 \\
(1.24)\end{array}$ & $\begin{array}{l}-4.32 \\
(1.47)\end{array}$ \\
\hline$p$-value for equal effects & 0.66 & 0.90 & 0.30 & 0.38 & 0.51 & 0.61 & 0.01 & 0.05 \\
\hline$R$-squared & 0.99 & 0.99 & 0.99 & 0.99 & 0.99 & 0.99 & 0.99 & 0.99 \\
\hline \multirow[t]{2}{*}{ observations } & 192 & 192 & 192 & 192 & 192 & 192 & 192 & 192 \\
\hline & \multicolumn{8}{|c|}{ B. ratio of candidates to seats } \\
\hline Post share $\times($ year $=2008)$ & $\begin{array}{l}-0.86 \\
(1.06)\end{array}$ & $\begin{array}{l}-0.99 \\
(1.18)\end{array}$ & $\begin{array}{l}-1.51 \\
(2.38)\end{array}$ & $\begin{array}{l}-0.93 \\
(2.40)\end{array}$ & $\begin{array}{l}-1.45 \\
(0.96)\end{array}$ & $\begin{array}{l}-1.55 \\
(0.90)\end{array}$ & $\begin{array}{l}-2.84 \\
(1.54)\end{array}$ & $\begin{array}{l}-2.49 \\
(1.63)\end{array}$ \\
\hline Post share $\times($ year $=2010)$ & $\begin{array}{l}-0.32 \\
(1.76)\end{array}$ & $\begin{array}{l}-1.28 \\
(1.34)\end{array}$ & $\begin{array}{l}-1.41 \\
(3.68)\end{array}$ & $\begin{array}{l}-1.17 \\
(3.77)\end{array}$ & $\begin{array}{c}0.86 \\
(1.86)\end{array}$ & $\begin{array}{l}-0.40 \\
(1.04)\end{array}$ & $\begin{array}{l}-1.45 \\
(2.53)\end{array}$ & $\begin{array}{l}-1.97 \\
(2.66)\end{array}$ \\
\hline$p$-value for equal effects & 0.80 & 0.88 & 0.97 & 0.93 & 0.21 & 0.42 & 0.47 & 0.77 \\
\hline$R$-squared & 0.87 & 0.89 & 0.93 & 0.93 & 0.86 & 0.88 & 0.93 & 0.93 \\
\hline \multirow[t]{2}{*}{ observations } & 192 & 192 & 192 & 192 & 192 & 192 & 192 & 192 \\
\hline & \multicolumn{8}{|c|}{ C. probability that winner is incumbent } \\
\hline Post share $\times($ year $=2008)$ & $\begin{array}{l}1.60 \\
(0.75)\end{array}$ & $\begin{array}{c}1.50 \\
(0.83)\end{array}$ & - & - & $\begin{array}{c}1.96 \\
(0.70)\end{array}$ & $\begin{array}{l}1.67 \\
(0.68)\end{array}$ & - & - \\
\hline Post share $\times($ year $=2010)$ & $\begin{array}{c}0.33 \\
(1.16)\end{array}$ & $\begin{array}{c}0.26 \\
(1.19)\end{array}$ & - & - & $\begin{array}{l}-0.23 \\
(0.95)\end{array}$ & $\begin{array}{l}-0.27 \\
(1.00)\end{array}$ & - & - \\
\hline$p$-value for equal effects & 0.32 & 0.32 & - & - & 0.05 & 0.04 & - & - \\
\hline$R$-squared & 0.38 & 0.41 & - & - & 0.36 & 0.40 & - & - \\
\hline \multirow[t]{2}{*}{ observations } & 144 & 144 & - & - & 144 & 144 & - & - \\
\hline & \multicolumn{8}{|c|}{ D. campaign spending per candidate $(\$)$} \\
\hline Post share $\times($ year $=2008)$ & $\begin{array}{l}-8585 \\
(8137)\end{array}$ & $\begin{array}{l}-2553 \\
(2946)\end{array}$ & $\begin{array}{l}-2360 \\
(2263)\end{array}$ & $\begin{array}{l}-1782 \\
(2165)\end{array}$ & $\begin{array}{l}-14878 \\
(10046)\end{array}$ & $\begin{array}{l}-4333 \\
(2543)\end{array}$ & $\begin{array}{l}-3257 \\
(1803)\end{array}$ & $\begin{array}{l}-2550 \\
(1475)\end{array}$ \\
\hline Post share $\times($ year $=2010)$ & $\begin{array}{l}-360 \\
(684)\end{array}$ & $\begin{array}{c}-992 \\
(772)\end{array}$ & $\begin{array}{l}10014 \\
(14451)\end{array}$ & $\begin{array}{c}292 \\
(3141)\end{array}$ & $\begin{array}{l}237 \\
(481)\end{array}$ & $\begin{array}{l}-895 \\
(605)\end{array}$ & $\begin{array}{l}19606 \\
(14548)\end{array}$ & $\begin{array}{l}2076 \\
(2094)\end{array}$ \\
\hline$p$-value for equal effects & 0.33 & 0.52 & 0.44 & 0.63 & 0.15 & 0.11 & 0.15 & 0.12 \\
\hline$R$-squared & 0.96 & 0.99 & 0.97 & 0.99 & 0.96 & 0.99 & 0.97 & 0.99 \\
\hline observations & 192 & 192 & 192 & 192 & 192 & 192 & 192 & 192 \\
\hline municipalitis & 48 & 40 & 40 & $T$ & 48 & 10 & 48 & 48 \\
\hline demographic controls & $\mathrm{N}$ & $\mathrm{Y}$ & $\mathrm{N}$ & $\mathrm{Y}$ & $\mathrm{N}$ & $\mathrm{Y}$ & $\mathrm{N}$ & $\mathrm{Y}$ \\
\hline municipality-specific trends & $\mathrm{N}$ & $\mathrm{N}$ & $\mathrm{Y}$ & $\mathrm{Y}$ & $\mathrm{N}$ & $\mathrm{N}$ & $\mathrm{Y}$ & $\mathrm{Y}$ \\
\hline
\end{tabular}

Standard errors clustered by municipality in parentheses. Estimates weighted by population age 18 and older in 2000 census. Panels A, B, and D use data from 2004, 2006, 2008, and 2010; panel C uses data from 2006, 2008, and 2010. Post share is average over 2004-2007 of the Post's share of stories in each year, with the 2003 share used as an instrument for instrumental variables estimates. All specifications include municipality and year fixed effects. Demographic controls are percentage of the population age 18 and older who are black and who are ages 18 to 34 and are interacted with year indicator variables. $p$-value for equal effects is $p$-value from a Wald $\chi^{2}$ test of the null hypothesis that the coefficients on Post share $\times($ year=2008) and on Post share $\times($ year=2010) are equal. 
Table 5: Effect of the Post's closure on Enquirer coverage.

\begin{tabular}{lccccc}
\hline & \multicolumn{2}{c}{ Ordinary least squares } & \multicolumn{2}{c}{ Instrumental variables } \\
\cline { 2 - 3 } Post share $\times($ year=2008) & 1.56 & 1.92 & 1.77 & 2.43 \\
& $(1.14)$ & $(1.15)$ & & $(1.21)$ & $(1.11)$ \\
Post share $\times($ year=2010) & 0.25 & -0.01 & 0.53 & 0.05 \\
& $(0.45)$ & $(0.33)$ & $(0.44)$ & $(0.29)$ \\
$p$-value for equal effects & 0.32 & 0.10 & 0.38 & 0.03 \\
$R$-squared & 0.83 & 0.84 & 0.83 & 0.84 \\
observations & 144 & 144 & 144 & 144 \\
municipalities & 48 & 48 & 48 & 48 \\
demographic controls & $\mathrm{N}$ & $\mathrm{Y}$ & $\mathrm{N}$ & $\mathrm{Y}$ \\
\hline
\end{tabular}

Standard errors clustered by municipality in parentheses. Estimates weighted by population age 18 and older in 2000 census. Data from 2006, 2008, and 2010. Post share is average over 2004-2007 of the Post's share of stories in each year, with the 2003 share used as an instrument for instrumental variables estimates. All specifications include municipality and year fixed effects. Demographic controls are percentage of the population age 18 and older who are black and who are ages 18 to 34 and are interacted with year indicator variables. $p$-value for equal effects is $p$-value from a Wald $\chi^{2}$ test of the null hypothesis that the coefficients on Post share $\times($ year $=2008)$ and on Post share $\times($ year $=2010)$ are equal.

change in Enquirer coverage in year $t$ relative to 2006. We calculate the percent change rather than taking the logarithm of stories in each year because some municipalities had zero Enquirer stories in 2008 and 2010. We take 2006 rather than 2007 as the baseline year for measuring Enquirer coverage because the Enquirer may have already begun to change its coverage in 2007 in anticipation of the Post's exit.

The estimates show that in 2008, Enquirer coverage rose relatively more in municipalities where the Post initially provided a larger share of coverage. The finding survives when we instrument for the Post's share, indicating that the result is not merely a consequence of reversion to the mean. Quantitatively, a one-standard-deviation increase in the Post's initial share led to an increase in Enquirer stories of 16 percent to 24 percent in the year after the Post closed. However, the effect was transitory: As of 2010, municipalities where the Post had been more important experienced little or no gains in Enquirer coverage. Unweighted estimates, reported in the appendix, are even more stark: The estimated increase in Enquirer coverage in 2008 is larger, and three of the four long-run estimates are negative. 
The Enquirer's transitory change in product positioning makes our results on political outcomes especially striking: Local politics changed when the Post closed even though its erstwhile competitor tried to replace the Post's coverage. In addition, if the Enquirer's added stories about towns with a high Post share came at the expense of stories about towns with a low Post share, then our estimates of the Post's political impact are lower bounds on the true impact: If the Post's closure caused the Enquirer to reduce coverage of the "control" municipalities where the Post was initially unimportant, then the differences between municipalities with high and low Post shares would be attenuated. ${ }^{22}$ Of course, the quantity of stories is an imprecise measure of how much information a newspaper provides. The quality of the Enquirer's stories - for example, their accuracy, timeliness, and readability - may differ from the quality of the Post's stories, either in all years or simply in 2008 or 2010, if the Post's exit changed the Enquirer's incentives for producing high-quality stories. The story count data do not measure such effects, if any. The story counts also do not measure any changes in coverage from other media. Growth of other media might explain how some political outcomes recovered by 2010 even though the Enquirer's added coverage did not last. The impact of newspaper closings on alternative media would be a valuable topic for future research.

\section{Conclusion}

The logo of the E.W. Scripps Co., printed on the front page of all its newspapers, is a lighthouse. This paper describes what happened when one of Scripps' lights went out. The Cincinnati Post was a relatively small newspaper, with circulation of only 27,000 when it closed. Nonetheless, its absence appears to have made local elections less competitive along several dimensions: incumbent advantage, voter turnout, campaign spending, and the number of candidates for office. The effect on voter turnout persisted for several years after the newspaper closed. We caution, however, that while our preferred point estimates tell a compelling story, the results are statistically imprecise and sometimes sensitive to the

\footnotetext{
${ }^{22}$ Since the Enquirer's total stories about the Kentucky municipalities fell slightly from 2006 to 2008, the increased coverage of towns with a high Post share tells us that coverage fell in towns with a low Post share. However, since we do not know what would have happened to Enquirer coverage if the Post had not closed, this finding does not prove that the Post's closure caused the Enquirer to reduce coverage of those towns.
} 
use of weights. In addition, this paper is a case study of the closing of one newspaper; future research could investigate the consequences of closings of other newspapers, though a significant challenge is to find an exogenous or at least predetermined closing.

Several other well-known newspapers have closed since the Post - the largest being Scripps' Rocky Mountain News, circulation 210,000, in February 2009 - and more are in danger. Observers are energetically debating whether these closings matter: Do newspapers play a valuable, irreplaceable role in American democracy, or can new media fill the gap left when a paper closes? Starr (2009) argues that the newspaper industry's decline "raises practical questions for anyone concerned about the future of American democracy." On the other hand, after the Rocky closed, U.S. Rep. Jared Polis, Democrat of Colorado, said the paper's demise was "mostly for the better" (Crummy, 2009). Whether our results support Starr's view or Polis' depends on how one values competitive elections. But if voter turnout, a broad choice of candidates, and accountability for incumbents are important to democracy, we side with those who lament newspapers' decline. 


\section{Appendix}

\section{A1. How weights affect the estimates}

Tables A.1 and A.2 investigate the effect of weights on our results by recalculating the estimates in tables 3 and 5, respectively, without weighting municipalities by voting-age population. For three of the four political outcomes, the results are qualitatively similar to what we obtained using weights: The Post's closing reduced the number of voters, reduced the ratio of candidates to seats, and reduced campaign spending. However, the estimated magnitudes of these effects are substantially smaller without weights in many specifications. For incumbent advantage, weights change the qualitative conclusion: Without weights, the Post's closing is estimated to have slightly decreased the chance an incumbent would win the election. When we examine Enquirer coverage, the unweighted estimates tell an even

sharper story than the weighted estimates: The estimated increase in Enquirer coverage of Post strongholds in 2008 is larger, while in three of the four specifications, the Post's closing had a slightly negative long-run effect on Enquirer coverage. 
Table A.1: Effect of the Post on political engagement and competition: unweighted estimates.

\begin{tabular}{|c|c|c|c|c|c|c|c|c|}
\hline \multirow[b]{3}{*}{ Post share $\times$ Post closed } & \multicolumn{4}{|c|}{ Ordinary least squares } & \multicolumn{4}{|c|}{ Instrumental variables } \\
\hline & \multicolumn{8}{|c|}{ A. $\ln$ (voters in general election) } \\
\hline & $\begin{array}{l}-0.21 \\
(0.41)\end{array}$ & $\begin{array}{l}-0.18 \\
(0.39)\end{array}$ & $\begin{array}{l}-1.14 \\
(1.18)\end{array}$ & $\begin{array}{l}-1.19 \\
(1.16)\end{array}$ & $\begin{array}{l}-0.61 \\
(0.71)\end{array}$ & $\begin{array}{l}-0.53 \\
(0.63)\end{array}$ & $\begin{array}{l}-2.11 \\
(1.47)\end{array}$ & $\begin{array}{l}-2.25 \\
(1.42)\end{array}$ \\
\hline$R$-squared & 0.98 & 0.98 & 0.98 & 0.98 & 0.98 & 0.98 & 0.98 & 0.98 \\
\hline \multirow[t]{2}{*}{ observations } & 192 & 192 & 192 & 192 & 192 & 192 & 192 & 192 \\
\hline & \multicolumn{8}{|c|}{ B. ratio of candidates to seats } \\
\hline Post share $\times$ Post closed & $\begin{array}{l}-0.08 \\
(0.42)\end{array}$ & $\begin{array}{l}-0.10 \\
(0.43)\end{array}$ & $\begin{array}{l}-0.10 \\
(0.62)\end{array}$ & $\begin{array}{l}-0.16 \\
(0.62)\end{array}$ & $\begin{array}{l}-0.15 \\
(0.37)\end{array}$ & $\begin{array}{l}-0.20 \\
(0.38)\end{array}$ & $\begin{array}{l}-0.29 \\
(0.47)\end{array}$ & $\begin{array}{l}-0.43 \\
(0.48)\end{array}$ \\
\hline$R$-squared & 0.67 & 0.68 & 0.80 & 0.80 & 0.67 & 0.68 & 0.80 & 0.80 \\
\hline \multirow[t]{2}{*}{ observations } & 192 & 192 & 192 & 192 & 192 & 192 & 192 & 192 \\
\hline & \multicolumn{8}{|c|}{ C. probability that winner is incumbent } \\
\hline Post share $\times$ Post closed & $\begin{array}{l}-0.37 \\
(0.43)\end{array}$ & $\begin{array}{l}-0.36 \\
(0.45)\end{array}$ & $\begin{array}{l}-0.64 \\
(1.08)\end{array}$ & $\begin{array}{l}-0.57 \\
(1.09)\end{array}$ & $\begin{array}{l}-0.31 \\
(0.32)\end{array}$ & $\begin{array}{l}-0.32 \\
(0.33)\end{array}$ & $\begin{array}{l}-0.38 \\
(0.49)\end{array}$ & $\begin{array}{l}-0.36 \\
(0.49)\end{array}$ \\
\hline$R$-squared & 0.46 & 0.47 & 0.78 & 0.79 & 0.46 & 0.47 & 0.78 & 0.79 \\
\hline \multirow[t]{2}{*}{ observations } & 144 & 144 & 144 & 144 & 144 & 144 & 144 & 144 \\
\hline & \multicolumn{8}{|c|}{ D. campaign spending per candidate (\$) } \\
\hline Post share $\times$ Post closed & $\begin{array}{l}-362 \\
(351)\end{array}$ & $\begin{array}{l}-197 \\
(334)\end{array}$ & $\begin{array}{l}-845 \\
(1126)\end{array}$ & $\begin{array}{l}-484 \\
(1064)\end{array}$ & $\begin{array}{l}-521 \\
(417)\end{array}$ & $\begin{array}{l}-287 \\
(314)\end{array}$ & $\begin{array}{l}-1255 \\
(1051)\end{array}$ & $\begin{array}{l}-759 \\
(858)\end{array}$ \\
\hline$R$-squared & 0.95 & 0.97 & 0.96 & 0.97 & 0.95 & 0.97 & 0.96 & 0.97 \\
\hline observations & 192 & 192 & 192 & 192 & 192 & 192 & 192 & 192 \\
\hline municipalities & 48 & 48 & 48 & 48 & 48 & 48 & 48 & 48 \\
\hline demographic controls & $\mathrm{N}$ & $\mathrm{Y}$ & $\mathrm{N}$ & $\mathrm{Y}$ & $\mathrm{N}$ & $\mathrm{Y}$ & $\mathrm{N}$ & $\mathrm{Y}$ \\
\hline municipality-specific trends & $\mathrm{N}$ & $\mathrm{N}$ & $\mathrm{Y}$ & $\mathrm{Y}$ & $\mathrm{N}$ & $\mathrm{N}$ & $\mathrm{Y}$ & $\mathrm{Y}$ \\
\hline
\end{tabular}

Standard errors clustered by municipality in parentheses. Panels A, B, and D use data from 2004, 2006, 2008, and 2010; panel C uses data from 2006, 2008, and 2010. Post share is average over 2004-2007 of the Post's share of stories in each year, with the 2003 share used as an instrument for instrumental variables estimates. All specifications include municipality and year fixed effects. Demographic controls are percentage of the population age 18 and older who are black and who are ages 18 to 34 and are interacted with year indicator variables. 
Table A.2: Effect of the Post's closure on Enquirer coverage: unweighted estimates.

\begin{tabular}{lccccc}
\hline & \multicolumn{2}{c}{ Ordinary least squares } & \multicolumn{2}{c}{ Instrumental variables } \\
\cline { 2 - 3 } Post share $\times($ year=2008) & 2.32 & 2.28 & 2.79 & 2.57 \\
& $(1.19)$ & $(1.20)$ & & $(1.21)$ & $(1.16)$ \\
Post share $\times($ year $=2010)$ & -0.01 & -0.06 & 0.02 & -0.12 \\
& $(0.49)$ & $(0.49)$ & $(0.40)$ & $(0.45)$ \\
$p$-value for equal effects & 0.09 & 0.09 & 0.03 & 0.04 \\
$R$-squared & 0.70 & 0.72 & 0.70 & 0.72 \\
observations & 144 & 144 & 144 & 144 \\
municipalities & 48 & 48 & 48 & 48 \\
demographic controls & $\mathrm{N}$ & $\mathrm{Y}$ & $\mathrm{N}$ & $\mathrm{Y}$ \\
\hline
\end{tabular}

Standard errors clustered by municipality in parentheses. Data from 2006, 2008, and 2010. Post share is average over 2004-2007 of the Post's share of stories in each year, with the 2003 share used as an instrument for instrumental variables estimates. All specifications include municipality and year fixed effects. Demographic controls are percentage of the population age 18 and older who are black and who are ages 18 to 34 and are interacted with year indicator variables. $p$ value for equal effects is $p$-value from a Wald $\chi^{2}$ test of the null hypothesis that the coefficients on Post share $\times($ year $=2008)$ and on Post share $\times($ year $=2010)$ are equal. 


\section{References}

Adserà, Alícia, Carles Boix, and Mark Payne, 2003, "Are You Being Served? Political Accountability and Quality of Government," Journal of Law, Economics, and Organization 19(2), 445-490.

Audit Bureau of Circulations, 2007, "County Penetration Reports," Nov. 7, 2007.

Baldasty, Gerald J., 1999, E.W. Scripps and the Business of Newspapers, Urbana, Ill.: University of Illinois Press.

Busterna, John C., and Robert G. Picard, 1993, Joint Operating Agreements: The Newspaper Preservation Act and its Application, Norwood, N.J.: Ablex Publishing.

Chun-Fang Chiang, and Brian G. Knight, forthcoming, "Media Bias and Influence: Evidence from Newspaper Endorsements," Review of Economic Studies.

Crummy, Karen E., 2009, "Bloggers killed Rocky, Polis asserts," Denver Post, March 2, downloaded March 3, 2009, from http://www.denverpost.com/news/ci_11820094.

Duke, Kerry, 2007, "Leaders lamenting demise of The Post," The Cincinnati Post, July 18.

Erikson, Robert S., 1976, "The Influence of Newspaper Endorsements in Presidential Elections: The Case of 1964," American Journal of Political Science 20(2), 207-233.

E.W. Scripps Co., 2004, "Newspaper JOA in Cincinnati will not be renewed after 2007," Jan. 16, news release downloaded March 3, 2009, from http://pressreleases.scripps.com/release/662.

E.W. Scripps Co., 2007, "The Cincinnati Post and The Kentucky Post to cease publication when JOA ends Dec. 31," July 17, news release downloaded March 3, 2009, from http://pressreleases.scripps.com/release/949.

Gentzkow, Matthew, 2006, "Television and Voter Turnout," Quarterly Journal of Economics 121(3), 931-972. 
Gentzkow, Matthew, Jesse M. Shapiro, and Michael Sinkinson, forthcoming, "Media Market Structure and Political Participation: Historical Evidence from U.S. Newspapers," American Economic Review.

George, Lisa M., and Joel Waldfogel, 2006, "The New York Times and the Market for Local Newspapers," American Economic Review 96(1), 435-477.

George, Lisa M., and Joel Waldfogel, 2008, "National Media and Local Political Participation: The Case of the New York Times," in Roumeen Islam, ed., Information and Public Choice: From Media Markets to Policymaking, 33-48. Washington: World Bank Publications.

Gerber, Alan S., Dean Karlan, and Daniel Bergan, 2009, "Does the Media Matter? A Field Experiment Measuring the Effect of Newspapers on Voting Behavior on Political Opinions," American Economic Journal: Applied Economics 1(2), 35-52.

Kahn, Kim Fridkin, and Patrick J. Kenney, 2002, "The Slant of the News: How Editorial Endorsements Influence Campaign Coverage and Citizens' Views of Candidates," American Political Science Review 96(2), 381-394.

Matsunaga, Rep. Spark (Hawaii), 1970, "Newspaper Preservation Act," Congressional Record 116:17, July 8, p. 23153.

Mondak, Jeffery J., 1995, "Newspapers and Political Awareness," American Journal of Political Science 39(2), 513-527.

National Election Pool, Edison Media Research, and Mitofsky International, 2004, "National Election Pool General Election Exit Polls, 2004," computer file distributed by Interuniversity Consortium for Political and Social Research.

National Election Pool, 2008, "National Election Pool General Election Exit Polls, 2008," downloaded March 13, 2009, from http://www.msnbc.msn.com/id/26843704.

Newspaper Preservation Act of 1970, 15 U.S.C. $§ 43$.

Oberholzer-Gee, Felix, and Joel Waldfogel, 2005, "Strength in Numbers: Group Size and Political Mobilization," Journal of Law and Economics 48(1), 73-91. 
Philipps, Mike, 2007, "Kentucky Post was a vital choice for more than a century," Cincinnati Post, downloaded Dec. 31, 2007, from http://news . cincypost. com/apps/pbcs . dll/article?AID=/20071231/LIFE/712310355/1005.

Rutledge, Mike, 2007, "An eye toward Kentucky," Cincinnati Enquirer, Dec. 30, p. E6.

Snyder, James M., Jr., and David Strömberg, 2010, "Press Coverage and Political Accountability," Journal of Political Economy 118(2), 355-408.

Starr, Paul, 2009, "Goodbye to the Age of Newspapers (Hello to a New Era of Corruption)," New Republic, March 4, 28-35.

Stevens, George Edward, 1968, A History of The Cincinnati Post. Ph.D. dissertation, University of Minnesota.

Trounstine, Jessica, 2009, "Information, Turnout, and Incumbency in Local Elections," manuscript, Princeton University. 